\title{
FACTORS INFLUENCING SMALL FARMERS' PARTICIPATION IN THE EXTENSION OF TEA FARMING: A CASE OF ILAM, NEPAL
}

\author{
Narendra Katuwal \\ Reader, Economics Education, Tribhuwan University, Mahendra Ratna Campus, Tahachal, Kathmandu, \\ Nepal.
}

Article DOI: $\underline{\text { https://doi.org/10.36713/epra6009 }}$

\begin{abstract}
Tea is one of Ilam's most significant sources of foreign exchange as well as a source of employment and income for the farmers. The quality of Ilam tea is actually among the best in the world but the quantity is still a challenge. In order to increase the quantity of the orthodox tea, farmers are encouraged to extend tea farms. The extension of land under tea cultivation in previous years, Importance of being a member of a cooperative, the source of credit, off-farm employment, the harvest quantity influenced extension positively to farmers while education level, the main occupation did not influence the participation of the farmers in the extension of tea farming. Based on the results the study recommends increasing the farmer's awareness to join the cooperative. It is suggested that the tea factory and infrastructures should be made easily available to minimize costs and increase benefits. The factors influencing small farmers' participation within the extension of tea farming were studied using both primary and secondary source of data through interviews with 196 tea farmers in Jitpur and Mangalbare areas of Ilam district as a case study. The participants were involved in tea cultivation at least for the last five years. In this study, a detailed analysis of the factors have been carried out.

KEYWORDS- cooperative, extension, factors, orthodox tea, small farmers.
\end{abstract}

\section{INTRODUCTION}

Regarding the beginnings of agricultural extension, the modern extension program has been connected to events that took place in Ireland in the middle of the 19th century. Between 1845-51the Irish potato crops were destroyed by fungal diseases and a serious famine occurred. The British Government planned for "practical instructors" to travel to rural areas and teach small farmers how to cultivate alternative crops (Jones \& Garforth, 1997). This program attracted the interest of government officials in Germany, who organized their own system of travelling instructors. By the end of the 19th century, the concept had spersed to Denmark, Netherlands, Italy, and France.

The phrase "university extension" was initially used by the Universities of Cambridge and Oxford in 1867 to describe teaching that extended the work of the institution beyond the campus. Most of these activities were not, however, relevant to agriculture. It was not until the starting of the 20th century when colleges in the United States began conducting delivering presentations at agricultural shows and delivering lectures to farmer's clubs, that, that the "extension service" was applied to the type of work that we now recognize by that term. Generally, there is some disagreement about whether or not the approach and

(c) 2020 EPRA ARER ｜ www.eprajournals.com ｜ Journal DOI URL: https://doi.org/10.36713/epra0813 
term of 'extension' really include four paradigms. Some experts believed that the term should be restricted to persuasive approaches, while others consider that it should only be used for educational. Paulo Freire has argued that the terms 'extension' and 'participation' are inconsistent. There are philosophical reasons regarding these disagreements. From a practical point of view, however, communication procedures that conform to each of these four paradigms are often being arranged under the extension in one part of the world or another (Fire, 1969). Pragmatically, whether not ideologically, more and more of such movements are regarded to be exemplified in agricultural extension.

The proposed study is focusing on influencing factors that small farmer participation on the extension of tea farming in Ilam, Nepal where tea has got a great potential for employment generation and export earnings. In 2006, the tea industry employed 105,000 Nepali people, especially females (International Trade Centre [ITC], 2007).

Moreover, most of the Nepali tea is cultivated by poor smallholder farmers (Heiss \& Heiss, 2007) and also tea cultivation and marketing can be a reliable driving force for poverty reduction (ITC, 2007). The Nepalese tea sector has experienced an average growth of $14 \%$ per annum since 2000 and the area under cultivation has reached 15,168 hectares in 2007 (FAO, 2009). In the same year, more than $90 \%$ of the orthodox tea produced in the hills of Nepal was exported to India and overseas markets (Agro Enterprise Center/Federation of Nepal Chamber of Commerce and Industries [AEC/FNCCI], 2009). Ilam is the leading district of tea production, followed by Panchthar, Dhankuta and Terahthum district. At the present 15234 farmers are involved in tea cultivation in Nepal. The whole plantation field of Nepal $28732 \mathrm{Ha}$. Ilam alone occupies more than 80 percent of total tea plantation area in which 7003 farmers are involved (Nepal Tea and Coffee Development Board [NTCDB], 2020).

Due to the varying climatic conditions and soil composition orthodox tea is actually cultivated in Ilam. A large number of smallholder farmers are engaged in tea growing in this district and their contribution in total production is increasing over the years as more small farmers are being attracted towards tea cultivation. Small farmers are organized into their respective groups through which they sell their leaves to the bought-leaf factories. These types of communities are federated into tea growers' cooperatives with like cooperatives in Ilam. Now, most of the farmers are gradually expanding their quantity of tea leaves production. It seems that small farmers are interested in the extension of their tea farming.

So, it is in this context that this research attempt to find out the factors that influence farmers in Ilam district to participate in the extension of tea farming and the limiting factors and constraints in tea production. An attempt has been made by this study to look answer of the questions-What are the factors that influence farmer's to participate in the extension of tea farming in Ilam district? And what are the challenges to which tea farmers' face within the extension of tea farming in Ilam District? This study aims to increase and deepen the knowledge to know the factors of extension that influencing tea production. Therefore, quantitative surveys with small tea farmers in the Nepalese tea sector are conducted. The objective of the study is to identify the factors influencing farmers to participate in the extension of tea farming in Ilam.

\section{METHODOLOGY}

This study was based on descriptive also known as an analytical research design. Similarly, this study tried to explore the influencing factors to farmer's participation in the extension of tea farming practices in Ilam, Nepal. Both primary and secondary data are employed in this research. The primary data were collected by interacting with different individuals from the selected respondents of Jitpur and Mangalbare area of Ilam. From reviewing relevant documents available on the web, provided by various agencies, like Bureau of Statistics, NGOs involved within the tea sector development of Nepal. The interview schedule, checklists, structured/unstructured interview, focus group discussion were adopted as research tools and techniques.

The interviews were semi-structured that addressed the challenges to which tea farmers' face within the extension of tea farming in Ilam. Altogether 196 farmers were interviewed. Both quantitative and qualitative data are created qualitatively or descriptively by using Statistical Package for social science (SPSS).

\subsection{Techniques of Data Collection}

The data was obtained from a comprehensive survey of tea farmers in Ilam district of eastern Nepal. Ilam district is the most popular ones for Nepalese tea production. Altogether two villages were visited for the study. The survey, conducted from November 2017 to February 2018, used face-to-face interviews to gather all relevant information from organic farmers. The core of the research took place in the Mangalbare (recently Deumai Municipality) and Jitpur VDC of the district of Ilam and included a collection of interviews with tea farmers in this area as well as interviews with tea experts. In this study, 100 farmers of 3 tea cooperatives were selected conveniently which were cultivating tea farming. First of all record and background information of the farmers was collected from the concerned cooperatives by using inventory collection form after, 
the questionnaire was designed to capture basic information on farmers' socio-demographic characteristics such as household size, age, gender, experience, and education. In order to understand farmers' demographic structure, small tea farmers were further asked about their motives for the participation on extension of tea production. Farmers' attitudes and motives towards farming were assessed through a series of statements which farmers were asked. The interviews were semi-structured that addressed the challenges and influencing factor of participation on extension of tea production in Nepal. The interviews were analyzed with the narrative analysis method. Narrative accounts follow courses of information and the phenomena under consideration, gather scattered information and explain why certain actions have taken place or how certain interactions happened (Richards, 1989). The method has been chosen because of its capacity to understand how people perceive and conceptualize actions. Similarly, a non-cooperative members 96, were also taken into account.

\subsection{Geographical location of the study area}

The study was utilized the information of the limited sample i.e. information available from the small tea farmers, tea activists (tea cooperatives authorities and tea promoters) and tea experts working in Ilam district. At present, it is reported that there are 3 clusters (called Chiya Bistar Yojana) working under Nepal Tea and Coffee Development Board in Ilam district namely Fikkal Chiya Bistar Yojana, Jasbire Chiya Bistar Yojana and Mangalbare Chiya Bistar Yojana. These three clusters covered the whole district in which 4201 ha land managed by 6123 farmers/producers (NTCDB, 2019). Among these three clusters Mangalbare cluster was be selected conveniently for field survey. It is reported that the total land under orthodox tea management in Mangalbare it is $2.93 \%$ (123 ha or 2476 ropani) of the total land covered by orthodox tea which is managed by $2.72 \%$ (167) of the total household heads/producers (Ibid).

These three cooperatives were selected for this study namely Ajambare Tea Cooperative Society, Nawami Tea Producer Cooperative Society and Hilltop Tea Producer Cooperative Society. In the selected cooperatives three are 100 members are taken as a sample in organic tea farming. Similarly, in the selected area, there are 7 small tea processing units running under private ownership.

Table 1: List of Cooperatives

\begin{tabular}{|c|c|c|}
\hline Name of the cooperatives & Address & $\begin{array}{c}\text { No. of } \\
\text { members }\end{array}$ \\
\hline Ajambare Tea Cooperative Society Ltd. & Jitpur VDC-2 & 66 \\
\hline Hill Top Tea Producer Cooperative Society Ltd & Deumai Municipality-5 & 74 \\
\hline Nawami Tea Producer Cooperative Society Ltd & Jitpur VDC-4 & 57 \\
\hline \multicolumn{2}{|c|}{ Total } & 206 \\
\hline
\end{tabular}

(Source: Field survey, 2019).

Table 2: Small Tea Processing Units

\begin{tabular}{|c|c|c|}
\hline Name Of The Processing Units & Address & Contact Persons \\
\hline Jalakanya Tea Industry Ilam & Mangalbare & Hem Lal Dhakal \\
\hline Shingha Devi Tea Processing Unit & Mangalbare & Ram KirshnaSubedi \\
\hline Himsikhar Tea Processing Industry & Mangalbare & Shree Kirshna Mani Prdhan \\
\hline Brothers Orthodox Tea ltd & Mangalbare & Raju Katuwal \\
\hline Kanchanjanga Organic Handmade Processing Unit & Sakhejung & Dambar Bahadur Khatri \\
\hline Lighthill Orthodox Tea Processing Industry & Sakhejung & Mohan Kumar Dahal \\
\hline Pathivara Orthodox Tea Processing Industry & Sakhejung & Motiram Dahal \\
\hline
\end{tabular}

(Source: Record of the Central Tea Cooperative Federation (CTCF) Ltd. Nepal, Ilam,2018)

\section{RESULT AND DISCUSSION}

This section presents the analysis and interpretation of the data to show whether the objectives are realized or not. First, the demographic characteristics of respondents are presented and the factors influencing farmer's participation in the extension of tea farming in the study area as a case study have been discussed.

(c) 2020 EPRA ARER ｜ www.eprajournals.com ～Journal DOI URL: https://doi.org/10.36713/epra0813 


\subsection{Farmer's extended tea area in Ilam}

The table 3. shows that the extension of tea area in Ilam was increased. The area was extended from
4189 hectares to 5920 hectares with an increasing of 1731 hectares.

Table 3: Farmer's Extended Tea Area and Production in Ilam

\begin{tabular}{|c|c|c|c|c|}
\hline Year & no. that small & Small Farmers & Additional growth in & Orthodox Tea \\
\hline $2011 / 2012$ & 6095 & 4189 & & 1804590 \\
\hline $2012 / 2013$ & 6137 & 4204 & 15 & 2449960 \\
\hline $2013 / 2014$ & 6372 & 4227 & 23 & 2743950 \\
\hline $2014 / 2015$ & 6985 & 4987 & 760 & 4146270 \\
\hline $015 / 2016$ & 6995 & 5120 & 133 & 4863250 \\
\hline $2016 / 2017$ & 6995 & 5120 & 0 & 4884830 \\
\hline $017 / 2018$ & 6995 & 5920 & 800 & 4982530 \\
\hline $2018 / 2019$ & 7003 & 5920 & 0 & 5096030 \\
\hline
\end{tabular}

Table 3 shows that the production of orthodox was increased near about two times in only eight years. The production was increased from $1804590 \mathrm{Kg}$ to $5096030 \mathrm{Kg}$ with an increasing of $3,291,440 \mathrm{Kg}$.

\subsection{Demographic Characteristics of small Tea Farmers}

The data that are socio-demographic data on farm size and basic conditions for farming and marketing shows that all of the 196 farmers cultivating their tea farms for the last five years. Among 196 farmers, near about $10 \%$ of the farmers are below 30 years old. Similarly, $29 \%$ of the farmers that are total aged between 41 and 50 years (Table 5).

Table 4: Composition of sample Tea Producer Cooperatives by ethnicity and sex

\begin{tabular}{|c|c|c|c|c|c|c|c|}
\hline \multirow{2}{*}{$\begin{array}{l}\text { Cast } \\
\text { Group }\end{array}$} & \multirow[t]{2}{*}{ Sex } & \multicolumn{3}{|c|}{ Name of The Tea Cooperatives } & \multirow{2}{*}{$\begin{array}{c}\text { Non } \\
\text { cooperativ }\end{array}$} & \multirow[t]{2}{*}{ Total } & \multirow[t]{2}{*}{$\%$} \\
\hline & & Ajambare & Nawam & Hilltop & & & \\
\hline \multirow{3}{*}{$\begin{array}{l}\text { Janajati } \\
\text { (Ethnic) }\end{array}$} & Female & 4 & 3 & 2 & 8 & 17 & 8.67 \\
\hline & Male & 15 & 5 & 8 & 27 & 55 & 28.06 \\
\hline & Total & 19 & 8 & 10 & 35 & 72 & 36.73 \\
\hline \multirow[t]{3}{*}{ Dalit } & Female & 0 & 2 & 1 & 2 & 5 & 2.55 \\
\hline & Male & 1 & 0 & 2 & 2 & 5 & 2.55 \\
\hline & Total & $\mathbf{1}$ & 2 & 3 & 4 & 10 & 5.10 \\
\hline \multirow[t]{3}{*}{ Other } & Female & 2 & 7 & 1 & 10 & 20 & 10.20 \\
\hline & Male & 13 & 21 & 13 & 47 & 94 & 47.96 \\
\hline & Total & 15 & 28 & 14 & 57 & 114 & 58.16 \\
\hline \multicolumn{2}{|c|}{ Grand Total } & 35 & 38 & 27 & 96 & 196 & 100.00 \\
\hline
\end{tabular}

Source: Field survey, 2019.

Table 4 shows that the majority of the farmers that are male (about $80 \%$ ) have managed their tea farms. In this case, only $42(20 \%)$ female have held their tea farming (Table 4).

The majority of caste that farming (58\%) in the study area belong to Brahman Chhetri (Other) groups.
The ethnic groups (Janajaties) are the second group that largest $(37 \%)$ in tea cultivation followed by only $5 \%$ Dalits are involved in tea cultivation (Table 5). 
Table 5: Descriptive analysis of Characteristics of Total Small Tea Farers

\begin{tabular}{|c|c|c|c|}
\hline \multicolumn{2}{|c|}{ 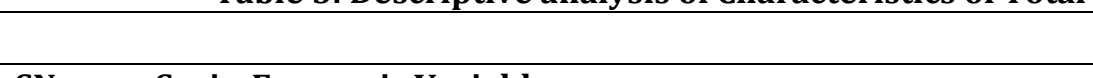 } & \multicolumn{2}{|c|}{ Small Farmers (N=196) } \\
\hline SN & Socio-Economic Variables & Mean(Std. & (\%) \\
\hline \multicolumn{4}{|c|}{ Personal Data } \\
\hline 1 & Gender of household head & & \\
\hline 1 & $1=$ Male, $0=$ Female & $0.79(0.41)$ & \\
\hline 2 & Age (years) & 46.86 & \\
\hline 2 & Less than 30 years & - & 9.69 \\
\hline 2 & 31 to 40 years & - & 24.49 \\
\hline 2 & 41 to 50 years & - & 28.57 \\
\hline 2 & 51 to 60 Years & - & 20.41 \\
\hline 2 & 61 and above & - & 16.84 \\
\hline 3 & Educational level & & \\
\hline 3 & $0=$ illiterate, $1=$ literate, $2=$ school level, $3=$ college and & $2.06(0.90)$ & \\
\hline 3 & Illiterate & & 0.00 \\
\hline 3 & Literate only & - & 37.24 \\
\hline 3 & School level & - & 19.90 \\
\hline 3 & College and university level & - & 42.86 \\
\hline 4 & Caste/Ethnicity & & \\
\hline 4 & 1= Janajati, $2=$ Dalit, 3= Other (Chhetri/ Brahman /Bhujel) & $2.21(0.95)$ & \\
\hline 4 & Janajati & - & 36.73 \\
\hline 4 & Dalit & - & 5.10 \\
\hline 4 & Other & - & 58.16 \\
\hline 5 & Family size (No. of household members) & $5.08(1.77)$ & \\
\hline 5 & Less than 5 members & - & 69.39 \\
\hline 5 & 6 to 10 members & - & 29.59 \\
\hline 5 & 11 to 15 members & - & 1.02 \\
\hline 6 & Experience in tea farming (years) & 15.87 & \\
\hline 6 & 5 to 10 years & - & 19.39 \\
\hline 6 & 11 to 15 years & - & 40.82 \\
\hline 6 & 16 to 20 years & - & 22.45 \\
\hline 6 & 21 to 25 years & - & 10.20 \\
\hline 6 & 26 to 30 years & - & 7.14 \\
\hline
\end{tabular}

(Source: Field survey, 2019)

A large portion of the farmers (43\%) have got a college or university education, but about $38 \%$ of the total farmers do not have any education that formal. They are under the "literate only' category. (Table 5).

The data reveals that small farmers are attracted to orthodox tea production. It was found that the average size of the tea firm is 0.45 hectare.

\subsection{Farmers' Influencing factors for Extension for Tea Farming in Ilam}

Almost all of the farmers answered in the affirmative to whether or not they like tea agriculture and the great majority said that the future of tea is well. Several farmers discussed that low (Rs. 40 to 45) offered for green leaves, explaining that a higher price needed for the farmers to gain a profit. It was found that many farmers seemed dissatisfied with the current price. Principal component factor analysis was 
performed to find farmers' motivation toward their participation on extension. It is possible to summarize factors as in the following 6 statements.

Factors that are influencing the farmers to extension of tea farming in Ilam, Nepal

Table 6: Tests of Between-Subjects Effects

\begin{tabular}{|c|c|c|c|c|c|c|}
\hline Sources & Dependent Variables & $\begin{array}{l}\text { Sum of } \\
\text { Square }\end{array}$ & df & $\begin{array}{l}\text { Mean } \\
\text { Square } \\
\end{array}$ & $\mathbf{F}$ & Sig. \\
\hline \multirow{6}{*}{$\begin{array}{l}\text { Extension of } \\
\text { land under tea } \\
\text { cultivation }\end{array}$} & $\begin{array}{l}\text { Educational level of } \\
\text { respondents }\end{array}$ & .401 & 1 & .401 & .693 & .406 \\
\hline & $\begin{array}{l}\text { Main (primary )occupation } \\
\text { Importance of being }\end{array}$ & 12.688 & 1 & 12.688 & 3.841 & .052 \\
\hline & member of cooperative & 27.005 & 1 & 27.005 & 6.612 & .011 \\
\hline & Access to credit & 10.060 & 1 & 10.060 & 7.466 & .006 \\
\hline & $\begin{array}{l}\text { Off-farm employment for } \\
\text { income }\end{array}$ & 2.514 & 1 & 2.514 & 10.851 & .001 \\
\hline & $\begin{array}{l}\text { The amount of tea } \\
\text { harvested }\end{array}$ & 5.716 & 1 & 5.716 & 34.009 & .000 \\
\hline
\end{tabular}

The result shows that six different influencing factors for the extension were found. Similarly, the farmers have been facing the constant problem of reliable workers. Due to the mass migrations of men to foreign countries for work, there was a shortage of skilled and unskilled workforce for cultivation and production in this sector. However, on the side that positive it has created job opportunities for the female population of the study area. Due to the lack of working men in the tea sector, the majority of workers are trained local women.

Influence of off-farm income on the extension of tea farming. The results that off-Farm earnings positively and significantly influenced the extension of tea cultivation (Table 6). The results disclosed that families obtaining off-farm earnings were more likely to invest in activities which extend tea production than families without off-farm. This could have many reasons such as purchasing land from non-farm, which may be also considered as collateral by financial institutions and informal loan providers. This may help to get loan and consequently to buy food or farming inputs.

Influence of membership to the cooperative on an extension of tea farming: The results showed that cooperative membership notably and definitely influenced the extension of tea farming (Table 6). It's understood that cooperatives play a mediator role between different stakeholders. Cooperative members had access to inputs, access to extension services, advocacy as well as produce market access.
Influence of harvested volume on extension of tea farming: The findings revealed that harvested volumes significantly and absolutely influenced the expansion of tea farming (table 6). The causes behind is that farmers who had increased yield/, had good yearly average farm net which in return supported them to get credits, buy land, provision of farm inputs extend tea activities.

Influence of the main (primary) occupation on the extension of tea farming: The findings revealed that the farmer's occupation hadn't affected the decision of farmers to take part in the extension of tea farming. This is because that over three-quarters of this sampled participants demonstrated which they were running only in the agriculture sector.

Influence of educational level of farmers on the expansion of tea farming: The education level of the farmer to extend the tea-growing (table 6) was tested and found that education level had any impact in the expansion of tea, the findings revealed it had no influence. The educated farmers are in formal employment, get credits from commercial banks and micro-finance institutions or big income off their businesses and purchase off-farm tasks, agro-business associated tasks and value chain deals.

Influence of other crops regarding the extension of tea farming: The study showed that other people crops influenced adversely to the decision of a farmer to increase the tea farming activities. 
Table 7: Five Crops Which Are Important in Ilam

\begin{tabular}{|l|c|c|l|c|c|}
\hline \multicolumn{3}{|c|}{ Users of Cooperative } & \multicolumn{3}{c|}{ Non- people of Cooperative } \\
\hline Factors under consideration & Counts & $\mathbf{\%}$ & Factors under consideration & Counts & $\%$ \\
\hline Maize & 31 & 31 & Maize & 27 & 28.13 \\
\hline Paddy & 17 & 17 & Paddy & 20 & 20.83 \\
\hline Cardamom & 21 & 21 & Cardamom & 22 & 21.12 \\
\hline Potato & 20 & 20 & Potato & 17 & 16.32 \\
\hline vegetables & 11 & 11 & Vegetables & 10 & 9.6 \\
\hline Total & 100 & 100 & Total & 96 & 100 \\
\hline
\end{tabular}

(Source: Field survey, 2019).

The reason is that in subsistence farming farmers widely utilize food crops a lot more than cash crops. The cropping patterns among the list of farming households had been driven by food security just as. The portion that is biggest of land is allotted to food crop (Table 7). Such behavior may have several explanations risk that is including, market transactions and more significantly lack of self-confidence in cash crops market. Nevertheless, harvests are not adequate to meet up with household food requirement, part the fraction of home expenditure on meals is high.

\subsection{Problems/challenges faced by smallholder tea farmers}

Tea has always been an important commodity for the Nepalese economy but smallholder tea producers were seriously affected by low prices and lack of incentives and resources to rehabilitate their export crops.
Among other challenges, the tea sector is facing are limited access to fertilizers for rural small tea growers as they're very expensive for them, limited industrial skills and limited processing capacity. Suboptimal delivery of fertilizers for both the industrial estates and the smallholder growers affect both quantity and quality of the green leaves produced.

The biggest challenge is limited basic infrastructure like roads and electricity which increase the price of production and has negative effects on the income of farmers. Lower prices for the green leaves have a negative impact on the way smallholder farmers handle the pruning and harvesting of their tea bushes. It is most important to get the leaves to the processing factory for processing as soon as possible because the fresh leaves deteriorate very quickly if not processed within hours of picking. In remote tea-growing areas, this will be a hindrance to making an excellent final product and doesn't allow producers to urge the total value of their product.

Table 8: Descriptive Analysis of Problems/Challenges Faced by Small Tea Farmers

\begin{tabular}{|l|c|c|}
\hline Problems/challenges & Farmers (frequency) & $\mathbf{\%}$ \\
\hline Lack of tea factory and basic infrastructures & 67 & 34.18 \\
\hline Labor source & 22 & 11.22 \\
\hline Small land size & 20 & 10.2 \\
\hline Problem of getting credits & 39 & 19.89 \\
\hline Low selling rate of green leaves & 33 & 16.84 \\
\hline Fertilizers and manure & 15 & 7.65 \\
\hline Total & 196 & 100 \\
\hline
\end{tabular}

(Source: field survey, 2019).

The study revealed that the problems/challenges are affecting negatively the tea production. The most important challenge mentioned by respondents with $34.18 \%$ of the small farmer is the lack of tea factory and basic infrastructure. The failure to build a factory at Ilam District for tea farmers has negative consequences because green leaves have to be transported to the nearest factory. This seriously reduces the quality of the tea. Due to the time required to evacuate the green leaves to the harvesting time at the plantation is reduced to no more than four hours a day, which also limits the production from the plantation. In addition, large quantities of tea leaves that arrive in those factories too late in the day for processing are actually thrown away ( $25 \%$ losses on average). 
Katuwal, (2020), in his article, reported that the organic tea farmers' input prices are higher. So, profits might not necessarily be higher under organic tea production. Similarly, farmers are facing the problem of reliable workers. Because of mass migrations of men to foreign countries for work, there's a shortage of skilled manpower for cultivation and production during this sector. However, on the positive side, it's created job opportunities for the feminine population of the study area. Because of the shortage of working men within the tea sector, the majority of workers are trained local women (Katuwal, 2020). Here also, the second big challenge specified by $11.22 \%$ of the farmer is labour shortage (Table 8).

The third challenge was that of getting loans from Agriculture Development Bank and commercial banks. Agriculture has traditionally been seen as a risk investment by banks and lots of them don't have collateral for accessing credits. The forth problems mentioned by respondent include small landholding size and minimum delivery of fertilizers which affect both the quantity and quality of the green leaves produced. Low prices for the green leaves $(40 \mathrm{Rs} / \mathrm{Kg})$ have a negative impact on the way smallholder growers handle the pruning and harvesting of their tea bushes. Among other burning problems; the results revealed that $88 \%$ of small farmers reported being paid late for green leaves.

\section{CONCLUSION}

The objective of the study was to assess the contribution of factors to the extension of tea farming in Ilam. The result shows that the access to credit, offfarm employment, quantity harvest, and the importance of being a member of the cooperative influenced positively on the extension of tea farming. The extension of the tea area was increased by 1.5 times in exactly seven years. The area was extended from 4189 hectares to 5920 hectares with an increase of 1731 hectares from 2011/12 to 2018/19 depending on the production, it had been increased from $1804590 \mathrm{Kg}$ to $5096030 \mathrm{Kg}$ with an increasing of 3,291,440 Kg of green leaves.

The study attempted to identify and analyze challenges that smallholding farmer's face in tea farming, which were found to have no significant difference between members and non-members. Those challenges were mainly related to the lack of tea factory, shortage of labour and global climate change, sub-optimal delivery of fertilizers, difficulties of getting credits from banks, being paid late for green leaves.

Based on the results from this study and the proposed solutions from the farmers to the main challenges, the following recommendations have been drown:

To increase the quantity of Ilam tea, the tea stakeholders should try to target specialty tea markets that provide price premiums which secure an adequate income for smallholding tea growers. The government and its stakeholders should support the farmers in need to build tea factories because the harvest must be available within a few hours of picking. The government needs to find ways to motivate the producers and encourage the availability of finance for a business start-up in the sector. The need for policymakers, particularly in the Government, to formulate policies that prioritize a free access to credit will support small tea farmers.

The NTCDB, Tea Cooperatives and other extension agents should create and intensify awareness campaigns and membership drives in the rural areas to encourage smallholding farmers to form or affiliate to tea cooperatives in Ilam so that they enhance their access to farming information as well as to have a joint bargaining power for farming services and inputs.

The need for the government and its development partners is to establish credit agencies in rural areas to enhance the farmers' awareness of the credit services and the access there of. The tea leaves buying factory should pay on time, what is due to the farmers in order to compensate for their hard work and help them to move out of poverty.

\section{REFERENCES}

1. AEC/FNCCI (2009). Tea. Kathmandu: Author (Text in Nepali). .

2. FAO (2009a). Production - Crops. FAOSTAT, Food and Agriculture Organzation of the United Nations

3. Freire, P. (1969) Extension y Comunicacion, translated by Louise Bigwood \& Margaret Marshall and re-printed in 'Education: The Practice of Freedom' (1976), Writers and Readers Publishing Cooperative

4. Heiss, M. L. \& Heiss, R. J. (2007). The Story of Tea: A Cultural History and Drinking Guide. USA: Ten Speed Press, Bekerely.

5. ITC (2007). Export Potential Assessment in Nepal. International Trade Centre (ITC), Geneva, Switzerland in collaboration with the Trade and Export Promotion Centre (TEPC) of Nepal. URL http://www.scribd.com/doc/49913984/Export-

Potential-Assessment-in-Nepal-2007.

6. Jones, G.E. \& Garforth, C. (1997) The history, development, and future of agricultural extension in Swanson, B. "Improving Agricultural Extension: A Reference Manual (3rd Edition)" FAO

7. Katuwal, N. (2020). Motivational Factors Influencing a Conversion for Organic Tea Farming In Napal, International Journal of current Research and Thought.(IJCRT). http://doi.one/10.1729/Journal.25079 
8. National Tea and Coffee Development Board (NTCDB) (2019,2020) Retrive fron https://www.teacoffee.gov.np/teaproduction

9. National Tea and Coffee Development Board [NTCDB] https://www.teacoffee.gov.np/statistics
10. Richards, R. J. (1989). Narrative Knowing and the Human Science. The American Journal of Sociology, Vol. 95, pp 258-260.

\section{AUTHORS PROFILE}

Mr Narendra Katuwal is currently working as a Reader in Department of Economics Education, Mahendra Ratna Campus, Tribhuwan University, Kathmandu. He is a Department Head in Economics Education since 2016. He has written reference and text books in Nepali and English medium and has already published research papers in reputed international journals that are available online. He has 25 years of teaching experience and now he is teaching History of Economic Thought in MR Campus, T.U. Kathmandu, Nepal. 